\title{
The Impacts of Calamity Logging on the Development of Spruce Wood Prices in Czech Forestry
}

\author{
Daniel Toth ${ }^{1, *}$, Mansoor Maitah ${ }^{2} \mathbb{D}$, Kamil Maitah ${ }^{3}$ and Veronika Jarolínová ${ }^{4}$ \\ 1 Department of Economics, Faculty of Forestry and Wood Sciences of the Czech University of Life Sciences in \\ Prague, Kamýcká 129, 16500 Prague, Czech Republic \\ 2 Department of Economics, Faculty of Economics and Management, Czech University of Life Sciences in \\ Prague, Kamýcká 129, 16500 Prague, Czech Republic; maitah@pef.czu.cz \\ 3 Department of Trade and Finance, Faculty of Economics and Management, Czech University of Life Sciences \\ in Prague, Kamýcká 129, 16500 Prague, Czech Republic; maitahk@pef.czu.cz \\ 4 Department of Law, Faculty of Economics and Management, Czech University of Life Sciences in Prague, \\ Kamýcká 129, 16500 Prague, Czech Republic; jarolinova@pef.czu.cz \\ * Correspondence: tothd@pef.czu.cz; Tel.: +420-606-810-534
}

Received: 10 February 2020; Accepted: 27 February 2020; Published: 29 February 2020

\begin{abstract}
Currently, the decline in spruce wood prices is a serious problem for the forestry sector in the Czech Republic. We estimate that the fall in wood prices in European markets causes losses not only to the forestry companies producing, harvesting, and processing the wood, but also to the workers in the sector. These losses are mainly caused by a combination of several natural factors: drought, climate change, and the effects of bark beetles. In particular, spruce bark beetles cause the greatest damage. Due to this bark beetle calamity, unplanned logging has increased. In 2019, these damages have culminated. Almost 100 million $\mathrm{m}^{3}$ of wood has been harvested over the last decade due to the bark beetle and more than half of this volume has been mined in the last four years. Therefore, the losses in the forestry sector are around EUR 1.12 billion. The aim of this study is an analysis of the relationship between the volume of incidental logging and the decline in the price of spruce wood. These results show the strong correlation between the measure of unplanned wood harvesting and the decrease in wood prices, as well as an estimate of price development if the upward trend of incidental mining continues. The average price of wood in the Czech Republic could thus reach a historical minimum of EUR 79.39 per $\mathrm{m}^{3}$ of spruce and category SM/JE II (spruce/fir). In addition, the decline in wood prices will be reflected in the management of forestry and timber businesses, including stagnant wages for forestry workers. The socio-economic impact of the bark beetle calamity is high and is most affected by the decline in spruce timber prices.
\end{abstract}

Keywords: unplanned logging; wood price; spruce; forest management; forest economy

\section{Introduction}

At present, Czech forestry is in crisis caused by climate change, drought, and the effects of biotic factors. The forests in the Czech Republic cover an area of 2,671,659 ha which is 34\% of the total land of the country. Czech forests are mainly owned by the Czech state, which owns $56 \%$ of all Czech forests. Municipalities own just 18\% and to private owners remain 26\% [1]. The economic impact of declining yields from forestry and logging, decreasing sales of infected wood, and stagnant forestry workers' wages are also contributing to this crisis. The first manifestation of this crisis began some ten years ago, sometime around 2009-2010. One of the most obvious effects is that the fall in the price of spruce wood, which is attacked by spruce bark beetle (Ips typographus, Pitogenes chalcographus, Ips duplicatus), must be harvested and dispatched from the forest in the shortest time possible. The spruce bark beetle, 
the most aggressive species of bark beetle, can spread very quickly; from one infected tree, another ten may be attacked.

The Czech Republic does not have sufficient capacity to process calamity wood and has to export its surpluses for unscheduled logging abroad. Germany and Austria have traditionally been the main trading partners for the Czech Republic. Most of the raw wood was exported to Austria for almost EUR 120 million. Wood was exported to Germany for EUR 80 million [2]. An alternative is to export the wood surplus to China. Exports to China can amount to EUR 120 million each year. China is increasing its demand for wood and imports more than 50 million $\mathrm{m}^{3}$ of wood material (i.e., wood and pulp) per year [3].

More than $42 \%$ of the harvested timber is purchased by German and Austrian partners on the basis of long-term contracts with Czech producers. In recent years this situation has changed somewhat since Chinese traders offer prices 10\% to 15\% higher than Austrian partners for Czech wood. For many timber producers, this is an increasingly appealing reason to export timber to China. However, they are limited not only by the number of containers available, but also by the limited logistics possibilities due to the size of the containers. More than $95 \%$ of China's exports are completed through shipping, with timber transported to trucks in the Adriatic and North Sea by truck or train. Transport by rail to China along the Silk Road would reduce logistic costs by about half and speed up imports to the destination country (within three weeks). China is the second largest importer of goods being sent to the Czech Republic; China will import goods worth over EUR 26 billion to the Czech Republic. On the contrary, only EUR 2.2 million worth of goods are exported from the Czech Republic to China [4].

In the European markets (Germany, Austria and Scandinavian countries), however, there is a surplus of wood and therefore a sharp fall in prices. The fall in prices will continue, so the aim of this study is to determine the relationship between the production of calamity logging and its impact on the average selling price of spruce wood. Economic theory suggests that an increase in the volume of some goods will be reflected in a short-term price decrease [2,4]. Therefore, our aim is to accurately determine and quantify how much the price of spruce wood will be reduced due to the additional production volume from unplanned calamity logging. This question can be answered with the help of a regression analysis, which will show us the possibility of estimating the price of spruce timber in the case of an additional increase in calamity logging by one unit; in our case, by one additionally harvested million $\mathrm{m}^{3}$ calamity wood.

Most of the total volume of logging in the Czech Republic is damaged by bark beetle. It has a much lower market price than timber from planned logging. However, there is no prior experience in selling such large quantities of bark beetle in the Czech Republic. In 2008, the devastating effect of the hurricane Kyrill caused damage mainly to the Klatovy district of the Czech Republic, where it destroyed almost three million $\mathrm{m}^{3}$ of wood. This means that one-third of the total damage in Europe fell to the Klatovy district. The hurricane lasted more than eight hours and the consequences were disastrous to the Bohemian Forest and the Sumava mountains. Over the next six months, the calamity wood was processed and gradually sold. However, the price fell by up to $25 \%$. Today, the calamity is much more extensive. Wood corrupted by biotic factors is much cheaper on the market [1,2,4].

\section{Materials and Methods}

A regression model was used in our methodical procedure [5,6]. It is a common statistical task in which the mutual dependence of two (or more) variables and its mathematical expression is determined. For this purpose, we use various regression methods and look for a suitable function $y=f(x)$, approximating the dependence between the measured quantities. One of the most common methods is the least squares method. Let us have $n$ measured pairs $\left[x_{i} ; y_{i}\right]$ by which we interleave the curve determined by the equation:

$$
\mathrm{y}=\mathrm{f}(\mathrm{x})
$$

We look for a function $f(x)$ that has the minimum sum of squares of $y$ coordinates of the measured points and the points lying on the interlaced curve: 


$$
\mathrm{S}=\sum_{\mathrm{i}=1}^{\mathrm{n}}\left(\mathrm{y}_{\mathrm{i}}-\mathrm{f}\left(\mathrm{x}_{\mathrm{i}}\right)\right)^{2}
$$

The mathematical calculation is based on partial derivatives, which are equal to zero $[5,6]$. Generally, this procedure can be applied to a number of functions $\mathrm{f}(\mathrm{x})$, but the most commonly used line is to approximate data:

$$
\mathrm{y}=\mathrm{f}(\mathrm{x})=\mathrm{k} \cdot \mathrm{x}+\mathrm{q}
$$

In our case, we will use linear regression. The exact derivation of the regression coefficients $k$ and $q$ is as following:

$$
\begin{gathered}
\mathrm{k}=\frac{\mathrm{n} \cdot\left(\sum_{\mathrm{i}=1}^{\mathrm{n}} \mathrm{x}_{\mathrm{i}} \mathrm{y}_{\mathrm{i}}\right)-\left(\sum_{\mathrm{i}=1}^{\mathrm{n}} \mathrm{x}_{\mathrm{i}}\right) \cdot\left(\sum_{\mathrm{i}=1}^{\mathrm{n}} \mathrm{y}_{\mathrm{i}}\right)}{\mathrm{n} \cdot\left(\sum_{\mathrm{i}=1}^{\mathrm{n}} \mathrm{x}_{\mathrm{i}} \mathrm{y}_{\mathrm{i}}^{2}\right)-\left(\sum_{\mathrm{i}=1}^{\mathrm{n}} \mathrm{x}_{\mathrm{i}}\right)^{2}} \\
\mathrm{q}=\frac{\left(\sum_{\mathrm{i}=1}^{\mathrm{n}} \mathrm{x}_{\mathrm{i}}^{2}\right) \cdot\left(\sum_{\mathrm{i}=1}^{\mathrm{n}} \mathrm{y}_{\mathrm{i}}\right)-\left(\sum_{\mathrm{i}=1}^{\mathrm{n}} \mathrm{x}_{\mathrm{i}}\right) \cdot\left(\sum_{\mathrm{i}=1}^{\mathrm{n}} \mathrm{x}_{\mathrm{i}} \mathrm{y}_{\mathrm{i}}\right)}{\mathrm{n} \cdot\left(\sum_{\mathrm{i}=1}^{\mathrm{n}} \mathrm{x}_{\mathrm{i}}^{2}\right)-\left(\sum_{\mathrm{i}=1}^{\mathrm{n}} \mathrm{x}_{\mathrm{i}}\right)^{2}}
\end{gathered}
$$

The suitability of using linear regression $[5,6]$ is justified by the correlation coefficient $r_{x y}$, whose value lies in the interval $<-1 ; 1>$. A straight-line approximation is justified if $\left|r_{x y}\right|>0.99$ (the two-nine rule). The following applies to the calculation:

$$
r_{x y}=\frac{\sum_{i=1}^{n}\left(x_{i}-\bar{x}\right)\left(y_{i}-\bar{y}\right)}{\sqrt{\sum_{i=1}^{n}\left(x_{i}-\bar{x}\right)^{2} \sum_{i=1}^{n}\left(y_{i}-\bar{y}\right)^{2}}}
$$

For deviations of the found regression coefficients, the following relations apply:

$$
\begin{gathered}
\sigma_{k}=\sqrt{\frac{S_{0}}{(n-2) \cdot\left[\sum_{i=1}^{n} x_{i}^{2}-\frac{1}{n} \cdot\left(\sum_{i=1}^{n} x_{i}\right)^{2}\right]}} \\
\sigma_{k}=\sqrt{\frac{S_{0} \cdot \frac{1}{n} \cdot \sum_{i=1}^{n} x_{i}^{2}}{(n-2) \cdot\left[\sum_{i=1}^{n} x_{i}^{2}-\frac{1}{n} \cdot\left(\sum_{i=1}^{n} x_{i}\right)^{2}\right]}} \\
S_{0}=\left(\sum_{i=1}^{n} y_{i}^{2}\right)-\frac{1}{n} \cdot\left(\sum_{i=1}^{n} y_{i}\right)^{2}-k \cdot\left[\sum_{i=1}^{n} x_{i} y_{i}-\frac{1}{n} \cdot\left(\sum_{i=1}^{n} x_{i}\right) \cdot\left(\sum_{i=1}^{n} y_{i}\right)\right]
\end{gathered}
$$

The confidence interval for the determination of regression coefficients, and hence their accuracy, depends on these variations and the selected probability $P$. The student's coefficient $t_{P,(n-1)}$ has the parameters $\mathrm{n}-1$ and $\mathrm{P}=95 \%$. Random extraction is indicated in our calculation as an independent variable $(X)$. We will refer to the average price of spruce wood in category SM/JE II (spruce/fir) as a dependent variable $(\mathrm{Y}) . \mathrm{M}_{\mathrm{x}}$ is the mean. $\mathrm{SS}_{\mathrm{x}}$ is the total sum of squares. The sum of squares $\left(\mathrm{SS}_{\mathrm{x}}\right)$ used to measure the amount of variability of a single variable is defined as:

$$
\mathrm{SS}_{\mathrm{x}}=\sum_{\mathrm{i}=1}^{\mathrm{n}}\left(\mathrm{X}-\mathrm{M}_{\mathrm{x}}\right)^{2}
$$

$\mathrm{SP}_{\mathrm{xy}}$ is the sum of products that is used to measure the variability shared between two variables. It is defined as:

$$
\mathrm{SP}_{\mathrm{xy}}=\sum_{\mathrm{i}=1}^{\mathrm{n}}\left(\mathrm{X}-\mathrm{M}_{\mathrm{x}}\right)\left(\mathrm{Y}-\mathrm{M}_{\mathrm{y}}\right)
$$

$\mathrm{SP}_{\mathrm{xy}}$ is an abbreviated designation for the sum of products corresponding to the variance scores for two variables. To calculate $\mathrm{SPX}_{\mathrm{s}}$, we first determine the deviation score for each $\mathrm{X}$ and for each $\mathrm{Y}$, then 
calculate the $\mathrm{SP}_{\mathrm{xy}}$ of each pair of deviation scores, and then add them up. A regression line is then created which expresses the linear dependence between the defined variables. Creating a regression line is based on general mathematical notation. A prerequisite for the existence of an extreme function of two or more variables is the zeroness of the first partial derivatives, in our case:

$$
\frac{\partial S^{2}\left(\beta_{1}, \beta_{2}\right)}{\partial \beta_{1}}=\frac{\partial S^{2}\left(\beta_{1}, \beta_{2}\right)}{\partial \beta_{2}}=0
$$

The condition is sufficient for the minimum need not be investigated, since the function $S\left(\beta_{1}, \beta_{2}\right)$ is purely convex. So we get:

$$
\begin{aligned}
& \frac{\partial S^{2}\left(\beta_{1}, \beta_{2}\right)}{\partial \beta_{1}}=2 \sum_{i=1}^{n}\left(y_{i}-\beta_{1}-\beta_{2} x_{i}\right)(-1)=0 \\
& \frac{\partial S^{2}\left(\beta_{1}, \beta_{2}\right)}{\partial \beta_{2}}=2 \sum_{i=1}^{n}\left(y_{i}-\beta_{1}-\beta_{2} x_{i}\right)\left(-x_{i}\right)=0
\end{aligned}
$$

We then obtain a system of normal equations:

$$
\begin{gathered}
\beta_{1} \mathrm{n}+\beta_{2} \sum_{\mathrm{i}=1}^{\mathrm{n}} \mathrm{x}_{\mathrm{i}}=\sum_{\mathrm{i}=1}^{\mathrm{n}} \mathrm{y}_{\mathrm{i}} \\
\beta_{1} \sum_{\mathrm{i}=1}^{\mathrm{n}} \mathrm{x}_{\mathrm{i}}+\beta_{2} \sum_{\mathrm{i}=1}^{\mathrm{n}} \mathrm{y}_{\mathrm{i}}^{2}=\sum_{\mathrm{i}=1}^{\mathrm{n}} \mathrm{x}_{\mathrm{i}} \mathrm{y}_{\mathrm{i}}
\end{gathered}
$$

We then use the system of equations as a tool for creating a regression model that can be used for the quantified estimate of the dependent variable, i.e., the price of raw spruce wood in category $\mathrm{SM} / \mathrm{JE}$ II (spruce/fir). In our research, it is necessary to investigate dependencies where there may not be a definite relationship between the observed traits (random variables). In this case, we are talking about statistical (stochastic) dependence [5,6]. We demonstrate this type of statistical dependence for both variables (variable $X$ is the volume of salvage logging and variable $Y$ is the price of spruce wood in class SM/JE II). Consequently, the null hypothesis can be formulated:

$$
\mathrm{H}_{0}: \rho_{X, Y}=0
$$

That is, there is no linear relationship between $\mathrm{X}$ and $\mathrm{Y}$. In the case of an alternative hypothesis, it makes sense to consider three options:

$$
\mathrm{H}_{\mathrm{A} 1}: \rho_{\mathrm{X}, \mathrm{Y}} \neq 0
$$

We select the two-way alternative if the calculated correlation coefficient is close to 0 .

$$
\mathrm{H}_{\mathrm{A} 2}: \rho_{\mathrm{X}, \mathrm{Y}}>0,
$$

We select the right-sided alternative if the calculated correlation coefficient is greater than 0 , so the sample indicates a positive linear dependence.

$$
\mathrm{H}_{\mathrm{A} 3}: \rho_{X, \mathrm{Y}}<0
$$

We select the left-sided alternative if the calculated correlation coefficient is less than 0 , so the sample indicates a negative linear dependence [5,6]. For verification, it is necessary to calculate $r$ :

$$
\mathrm{r}=\sum_{\mathrm{i}=1}^{\mathrm{n}}\left(\frac{\mathrm{Y}-\mathrm{M}_{\mathrm{x}}}{\sqrt{\left(\mathrm{SS}_{\mathrm{x}}\right)\left(\mathrm{SS}_{\mathrm{y}}\right)}}\right)
$$


The Parsons correlation coefficient determines whether it is a linear regression dependency, a right-hand alternative, or a left-hand alternative. Only then can the hypothesis be evaluated (reject zero and accept one of the alternative hypotheses). However, the prices of spruce wood vary both in terms of quality classes and in relation to the species assortment. Therefore, we took the price of spruce wood in class SM/JE II (i.e., without damage by wood-destroying insects and fungi) as the initial average price because it is the best-selling assortment of timber both on the domestic and foreign markets. Today, there are two types of this class II product on the market: one without the previous occurrence of bark beetle damage and one with the previous occurrence of bark beetle, but without damage. These are debarked strains, in which, besides the color change, there are no other visible signs of bark beetle. These strains have the same physical and visual characteristics as spruce wood that is wholly healthy. If we take the total average price as a starting point, including class I to class $\mathrm{V}$ (which is firewood), then we get to an average price somewhere between 25 to $25.79 \mathrm{EUR} / \mathrm{m}^{3}$.

Given that the data used are valid and verified, the standard methodology yields clear results. The data that was used (primarily source data) comes mainly from the Czech Statistical Agency. The data was also verified empirically. Random extraction is an indicator that the Czech Statistical Agency monitors at yearly intervals and publishes the results for the quarter. Accurate data for a decade was available and price indicators are also official from the Czech Statistical Agency. We based our findings on the prices collected, not the prices demanded by the timber producers (offer price). We obtained a time series of prices by taking the average of the prices actually received by timber producers.

\section{Results}

However, prices may also vary regionally. For example, in regions with the highest incidence of bark beetle and here with the highest volume of incidental logging, spruce wood prices may fall below EUR 39.67 per $\mathrm{m}^{3}$. Before bark beetle calamity, prices for the same wood could be three times higher in the same region [4].

The graphs in Figure 1 show the development of incidental mining between 2009 and 2019. On the $y$-axis, we can see the volume of mining in thousands of $\mathrm{m}^{3}$. In 2019, the accidental extraction facility in the Czech Republic reaches more than 30 million $\mathrm{m}^{3}$. In the last four years, the volume of incidental mining in the Czech Republic has been growing at an almost exponential rate. On the right side (Figure 1), we see the development of the price of spruce wood. This is the average price of spruce wood in class SM/JE II. Over the past decade, prices have been decreasing at a homogeneous linear rate. The development of both indicators is favorable for the use of regression analysis. Therefore, linear regression was evaluated as optimal for estimation. The average price of spruce wood is a dependent variable and the volume of incidental logging is an independent variable.

Table 1 lists the auxiliary calculations for the regression analysis. The first column shows the deviations from the average of the independent variable $X$, the second column shows the deviations from the average of the dependent variable, respectively, from the average price of raw spruce (Y). The third column shows the calculations for the sum of variance $\left(\mathrm{SS}_{\mathrm{xy}}\right)$. The last column shows $\mathrm{SP}_{\mathrm{xy}}$ data, which is an abbreviation for the sum of products corresponding to the variance scores for the two variables $X$ and $Y$. These data are then used to calculate the linear regression model shown in Table 2.

Table 1. Statistics for linear regression.

\begin{tabular}{|c|c|c|c|}
\hline $\mathbf{X}-\mathbf{M}_{\mathbf{x}}$ & $\mathbf{Y}-\mathbf{M}_{\mathbf{y}}$ & $(\mathrm{X}-\mathrm{Mx})^{2}$ & $\left(\mathrm{X}-\mathrm{M}_{\mathrm{x}}\right) \cdot\left(\mathrm{Y}-\mathrm{M}_{\mathrm{y}}\right)$ \\
\hline-6250.9 & 521.5 & $39,073,750.81$ & $-3,259,844.35$ \\
\hline-5889.9 & 502.5 & $34,690,922.01$ & $-2,959,674.75$ \\
\hline-6472.9 & 481.5 & $41,898,434.41$ & $-3,116,701.35$ \\
\hline-5461.9 & 321.5 & $29,832,351.61$ & $-1,756,000.85$ \\
\hline-5182.9 & 309.5 & $26,862,452.41$ & $-1,604,107.55$ \\
\hline
\end{tabular}


Table 1. Cont

\begin{tabular}{cccc}
\hline $\mathbf{X}-\mathbf{M}_{\mathbf{x}}$ & $\mathbf{Y}-\mathbf{M}_{\mathbf{y}}$ & $(\mathbf{X}-\mathbf{M x})^{\mathbf{2}}$ & $\left(\mathbf{X}-\mathbf{M}_{\mathbf{x}}\right) .\left(\mathbf{Y}-\mathbf{M}_{\mathbf{y}}\right)$ \\
\hline-1556.9 & -231.5 & $2,423,937.61$ & $360,422.35$ \\
\hline-310.9 & -297.5 & $96,658.81$ & $92,492.75$ \\
\hline 2033.1 & -300.5 & $4,133,495.61$ & $-610,946.55$ \\
\hline $13,303.1$ & -448.5 & $176,972,469.61$ & $-5,966,440.35$ \\
\hline $15,790.1$ & -858.5 & $249,327,258.01$ & $-13,555,800.85$ \\
\hline & & SS: $605,311,730.9$ & SP: $-32,376,601.5$ \\
\hline
\end{tabular}

Source: own calculations. SS: The sum of squares; SP: the sum of products.

The salvage felling in thousand $\mathrm{m}^{3}$

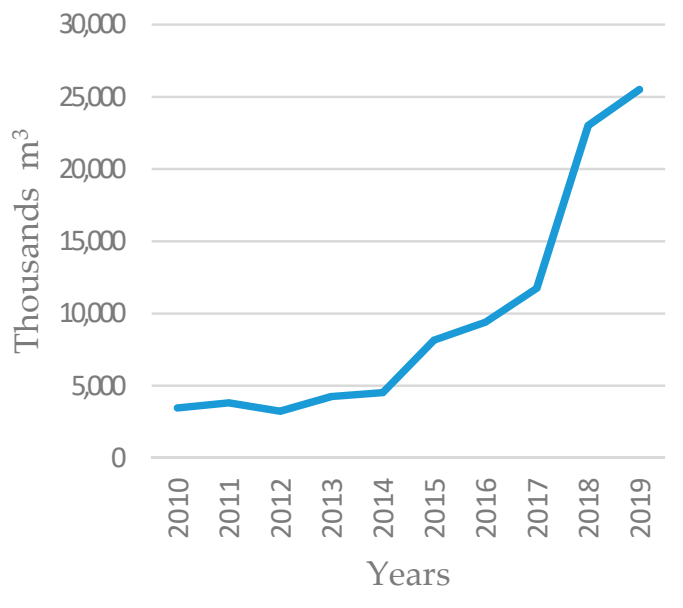

The average price of spruce wood $\left(\mathrm{EUR} / \mathrm{m}^{3}\right)$

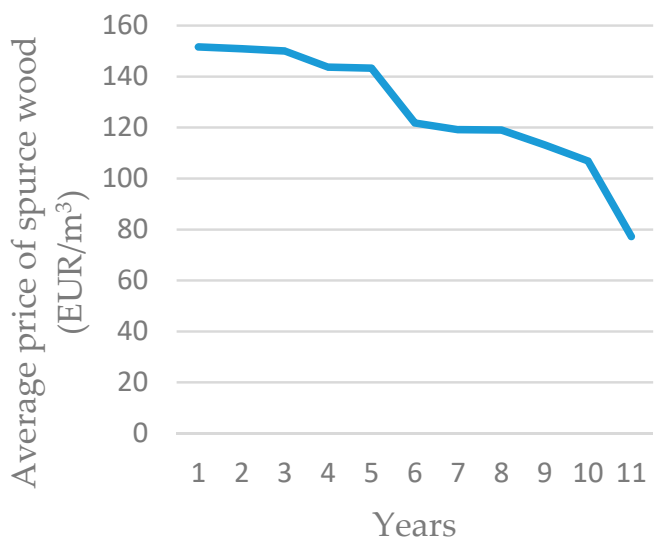

Figure 1. The calamity logging and price of spruce wood; Source: ČSU (Czech Statistical Agency), 2019.

Table 2. Summary results of linear regression calculation.

\begin{tabular}{cc}
\hline Sum of $\mathbf{X}$ & 97,099 \\
\hline Sum of $\mathbf{Y}$ & 32,985 \\
\hline Mean $\mathbf{X}$ & 9709.9 \\
\hline Mean $\mathbf{Y}$ & 3298.5 \\
\hline Sum of squares (SS $\mathbf{X})$ & $605,311,730.9$ \\
\hline Sum of products (SP) & $-32,376,601.5$ \\
\hline Regression equation & $\hat{\mathrm{y}}=\mathrm{bX}+\mathrm{a}$ \\
\hline Calculation of parameter a & $\mathrm{a}=\mathrm{M}_{\mathrm{y}}-\mathrm{b} \cdot \mathrm{M}_{\mathrm{x}}=$ \\
\hline Calculation of parameter $\mathbf{b}$ & $3298.5-(-0.05 \cdot 9709.9)=3817.85812$ \\
\hline Regression equation & $\hat{\mathrm{S}}=-0.05349 \mathrm{X}+3817.85812$ \\
\hline Correlation coefficient- equation & $\mathrm{r}=\sum_{\mathrm{i}=1}^{\mathrm{n}}\left(\frac{\mathrm{Y}-\mathrm{M}_{\mathrm{x}}}{\sqrt{\left(\mathrm{SS}_{\mathrm{x}}\right)\left(\mathrm{SS}_{\mathrm{y}}\right)}}\right)$ \\
\hline Correlation coefficient-calculation result & $r=\frac{-32376601.5}{\sqrt{(605311730.9) \cdot(2126036.5)}}=-0.9025$ \\
The value of the correlation coefficient $(\mathbf{R})$ is $-\mathbf{0 . 9 0 2 5}$
\end{tabular}


Table 2 shows the main results of the regression equation as a tool for estimating the price of raw spruce wood in 2020 . Using the regression equation $\hat{y}=-0.05349 X+3817.85812$, we can predict the development of raw spruce wood prices and the future projected volume of bark beetle extraction (or, more precisely, incidental extraction). In Table 3, the result of this calculation and the estimation of the price of raw spruce wood are shown. If we expect a yearly unplanned logging of spruce wood of 35 million $\mathrm{m}^{3}$, the price of spruce wood can be expected to fall to EUR 73/ $\mathrm{m}^{3}$. The calculations show that the null hypothesis $\left(\mathrm{H}_{0}: \rho_{X}, \mathrm{Y}=0\right)$, can be rejected since there is no linear relationship between $\mathrm{X}$ and $Y$. Thus, an alternative $\mathrm{H}_{\mathrm{A} 3}$ hypothesis can be accepted: $\left(\mathrm{H}_{\mathrm{A} 3}: \rho_{X, Y}<0\right)$, the so-called left-hand alternative. The calculated correlation coefficient -0.9025 is less than 0 , which means that the sample indicates a negative linear relationship.

Table 3. The volume of salvage logging and the price of spruce wood (in EUR) between the years 2010 and 2020.

\begin{tabular}{ccc}
\hline Incidental Mining 2010-2020 & Thousand $\left.\mathbf{~}^{\mathbf{3}} \mathbf{(}_{\mathbf{i}}\right)$ & Price of Spruce Wood in EUR $\left(\mathbf{Y}_{\mathbf{i}}\right)$ \\
\hline 2010 & 3459 & 151 \\
\hline 2011 & 3820 & 150 \\
\hline 2012 & 3237 & 150 \\
\hline 2013 & 4248 & 144 \\
\hline 2014 & 4527 & 143 \\
\hline 2015 & 8153 & 112 \\
\hline 2016 & 9399 & 119 \\
\hline 2017 & 11,743 & 119 \\
\hline 2018 & 23,013 & 107 \\
\hline 2019 & 25,500 & 77 The Calculation result \\
\hline 2020 & 35,000 The Estimate & \\
\hline Source: own calculations, ČSU (Czech Statistical Agency) 2019, Forestry.
\end{tabular}

Using a linear regression model, it is possible to estimate price developments over a short period (Table 3). The development of the volume of unplanned logging was designed to correspond to the maximum estimated growth in the volume of logging. Next year, logging should reach $35 \mathrm{million}^{3}$ of wood. The graph in Figure 1 shows a fall in the price of raw wood below the limit of EUR 79 per $\mathrm{m}^{3}$. Taking into account the development over the entire decade, at the beginning of the decade (in 2010), the price of raw spruce wood reached almost EUR $159 / \mathrm{m}^{3}$. If we consider the price of $159 \mathrm{EUR} / \mathrm{m}^{3}$ at the beginning of the decade, then we expect half the price next year.

The estimated price of spruce wood in 2020 will be at the current volume of incidental logging below the limit of 80 EUR for one $\mathrm{m}^{3}$. This is historically the lowest price that spruce wood producers will receive in the Czech Republic (Figure 2).

Almost 100 million $\mathrm{m}^{3}$ of wood has been harvested over the last decade due to damage by the bark beetle. More than half of this volume has been mined in the last four years. Therefore, the financial losses in the forestry sector are around EUR 1.12 billion. Losses in the sector may continue to increase since the forest will need to be restored in the next three years. At present, the traditional method of manual planting, with little technological assistance, prevails. Forest restoration is thus based on human work which is currently scarce; the forestry sector in the Czech Republic currently lacks more than 4000 workers. The labor shortages are temporarily compensated for by foreign workers. However, in the long term, it will be necessary to provide qualified and sufficiently motivated workers for forest regeneration.

Figure 3 shows a strong dependence of the selected variables using the linear regression model. The results correspond to the assumption that the volume of unplanned logging caused by biological 
factors effects both the volume of harvested wood and the resulting price. At the beginning of the decade, wood production and prices did not change much, as shown by the left side of the curve. Gradually, with the increased volume of logging, the prices of spruce damaged by bark beetle started to fall to values around $99 \mathrm{EUR} / \mathrm{m}^{3}$. The linear regression model has a relatively high validity; the determination index $\left(R^{2}\right)$ shows that $81.5 \%$ of the variables correspond to the selected model. Based on the regression model $[5,6]$, the development of the price of raw spruce wood can be predicted only in the short term.

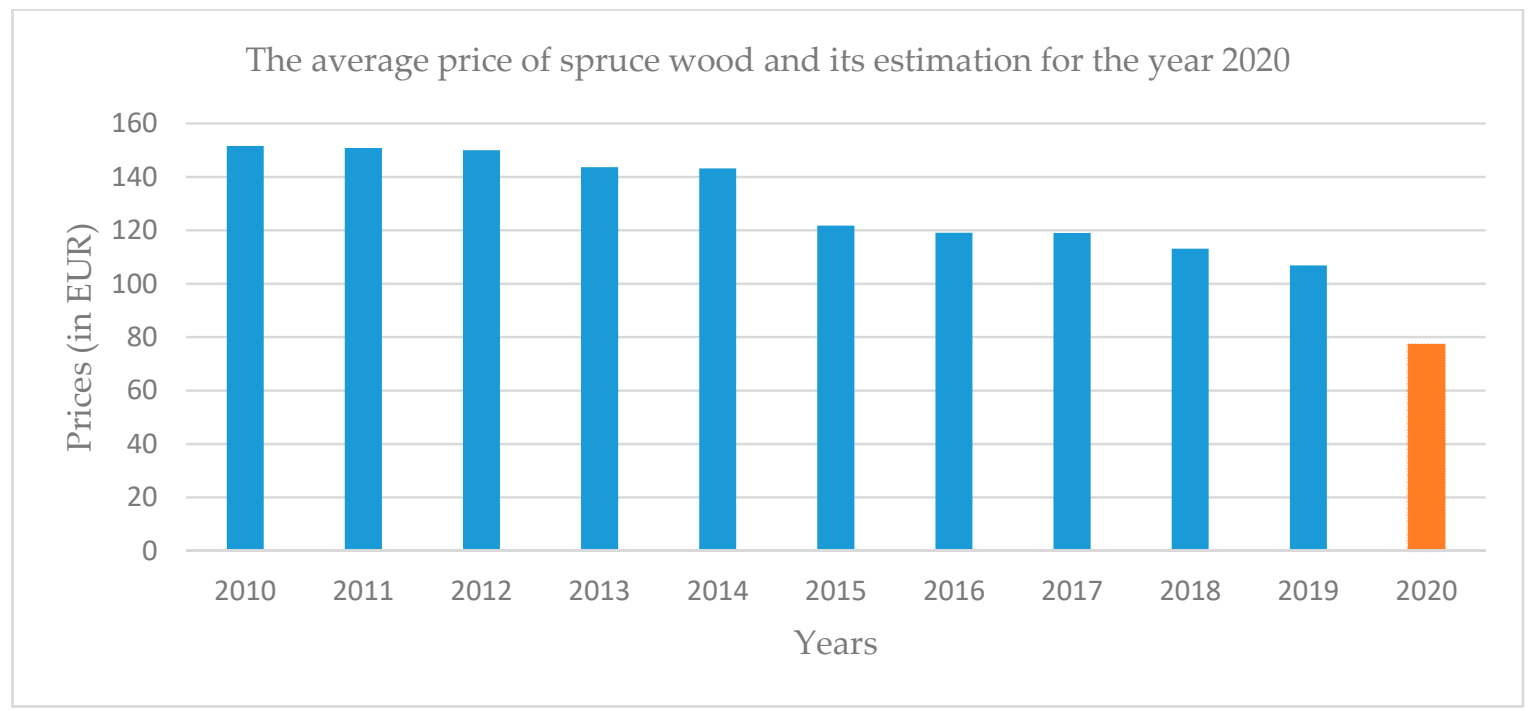

Figure 2. The average price of spure and fir sortiment in the quality SM/JE II and the estimated price for the year 2020. Source: own calculations.

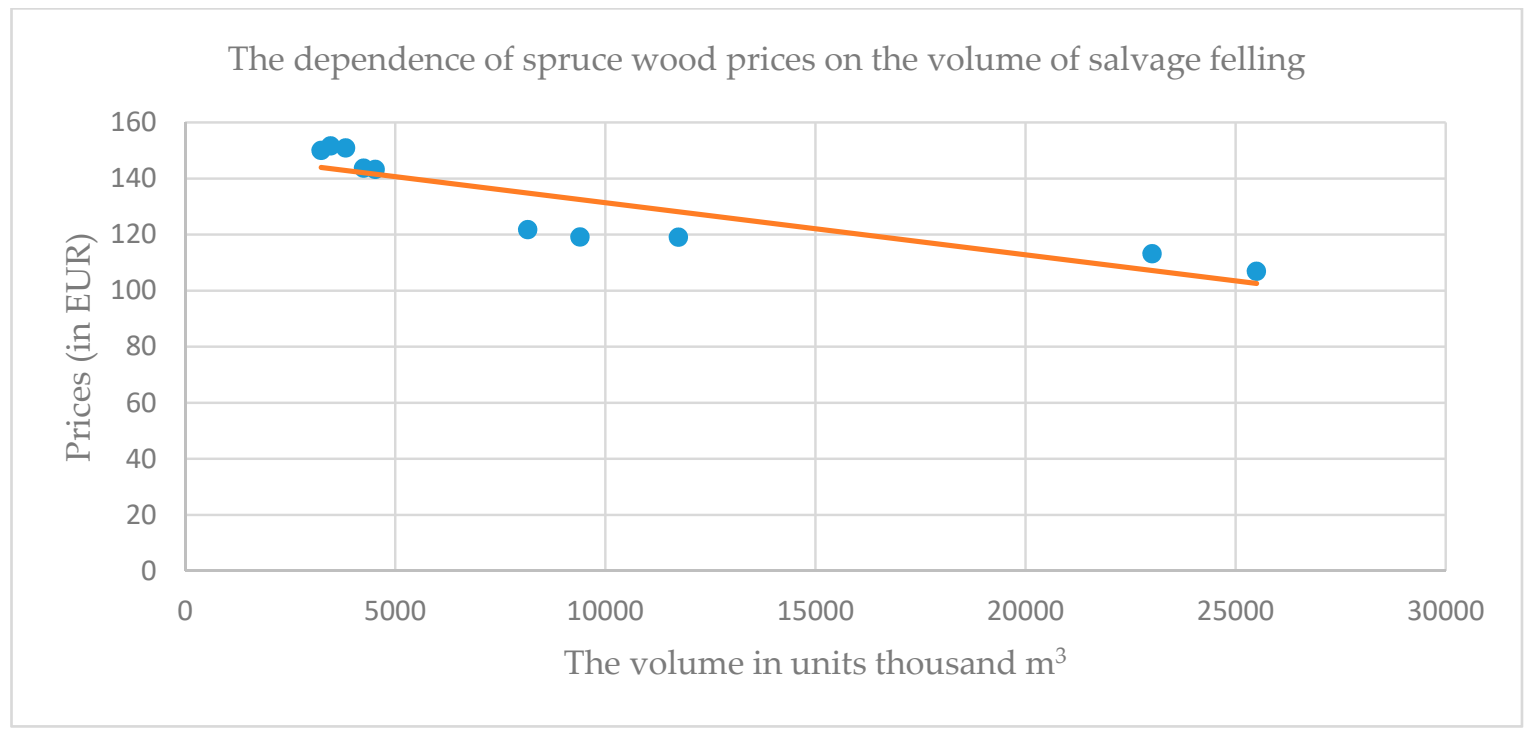

Figure 3. The dependence of the price of spruce wood on the volume of random logging-linear regression model. Source: own calculations; linear regression model: $\mathrm{y}-0.0469 \mathrm{x}+3779.2 ; R^{2}=0.8145$.

Over a longer period of time, prices will depend on where the export of calamitic timber goes. If the amount of exports to China increases, it can be expected that the rate of decline in prices will slow since Chinese partners offer up to $15 \%$ better prices for spruce wood than traditional partners, especially Austrian partners. Moreover, China does not have such stringent requirements for wood quality. In most cases the requirements are limited to meeting common standards without the need for European certification. The trunks must be cut to a size of $11.8 \mathrm{~m}$ in order to be transported into 
shipping containers and the wood is imported to China by ship. The projected volume of exports to China for 2020 is EUR 80 million [3]. The value of wood which was exported last year to Germany reached 80 milions EUR while to Austria the export value was 120 miilions EUR. This year, exports to China could amount to up to EUR 120 million [3]. China is increasing their demand for wood and imports more than 50 million cubic meters of wood material annually. Czech spruce producers, who are forced to mine double the volume of spruce because of the bark beetle epidemic, may be reduced by Chinese customers by millions of EUR. German and Austrian producers may also resort to the efficient exportion of spruce wood.

An alternative model that can be used is an exponential, nonlinear regression model. The nonlinear regression model is used to predict and estimate wood prices. The nonlinear regression model has a determination index $\left(\mathrm{R}^{2}\right)$ of 0.93 (Figure 4 ). This means that $93.5 \%$ of the estimated variables correspond to the chosen model. The model can be considered valid and based on the regression equation $y=$ $18058 x-0.192$. We can also estimate the evolution of spruce prices.

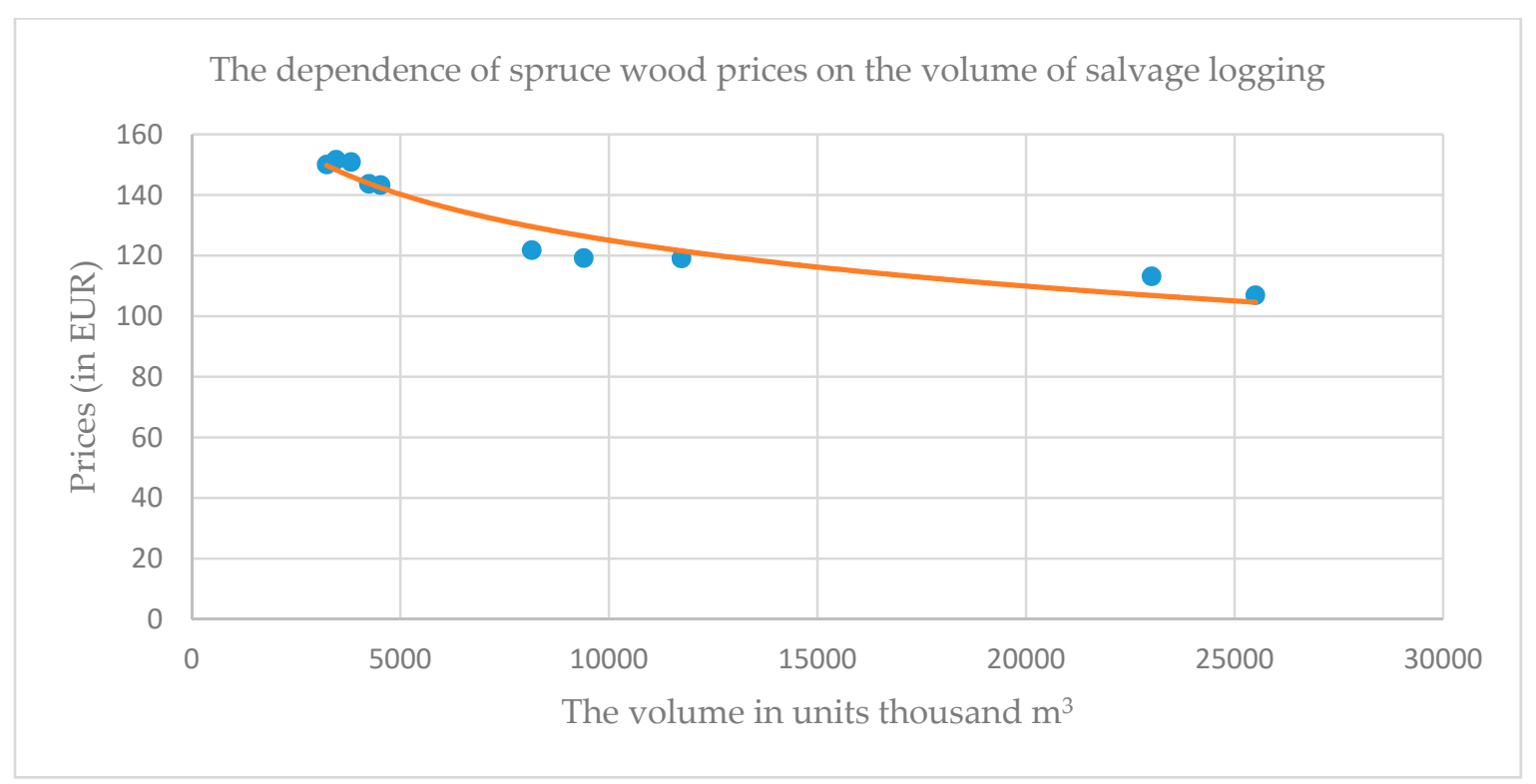

Figure 4. The dependence of the price of spruce wood on the volume of random logging-exponential model. Source: own calculations; exponential regression model: $y=18058 x^{-0.192} ; R^{2}=0.9343$.

For the interpretation of our data, it is useful to observe the regression coefficient $R^{2}$ in relation to the correlation coefficient $r$. Since this prediction will always be inaccurate, $R^{2}$ helps us estimate how much error there will be in our estimates. Significance data indicates whether or not our estimate is due to a sampling error. A significance of less than 0.05 (which is not the case now) indicates that our result is not due to sampling error and we can therefore expect it in the population. The values of the dependent variable and the price of raw spruce wood in class SM/JE II will arise as the product of the regression coefficient value and the expected value. The constant shows how high the value of the dependent variable is when the value of the independent variable is zero. The regression coefficient value shows how much the value of the dependent variable $Y$ changes when the value of the independent variable is increased by the unit in which it is measured. We can then use the regression equation to estimate the price of spruce wood as a function of the volume of unplanned logging (according to the relation: $\hat{y}=-0.0506 x+3806.5)$. If unplanned logging exceeds $35 \mathrm{million}^{3}$, ceteris paribus (the price of spruce wood for $1 \mathrm{~m}^{3}$ ) will fall below EUR 79 (Figure 5). When unplanned logging is increased by 1 million $\mathrm{m}^{3}$, the price of $1 \mathrm{~m}^{3}$ of spruce wood (in category SM/JE II) is reduced by 4.2 million EUR. Therefore, the price of spruce wood (in category SM/JE II) decreases annually by approximately 10\% (the growth index between 2018/2019 was $90.1 \%$ ). 


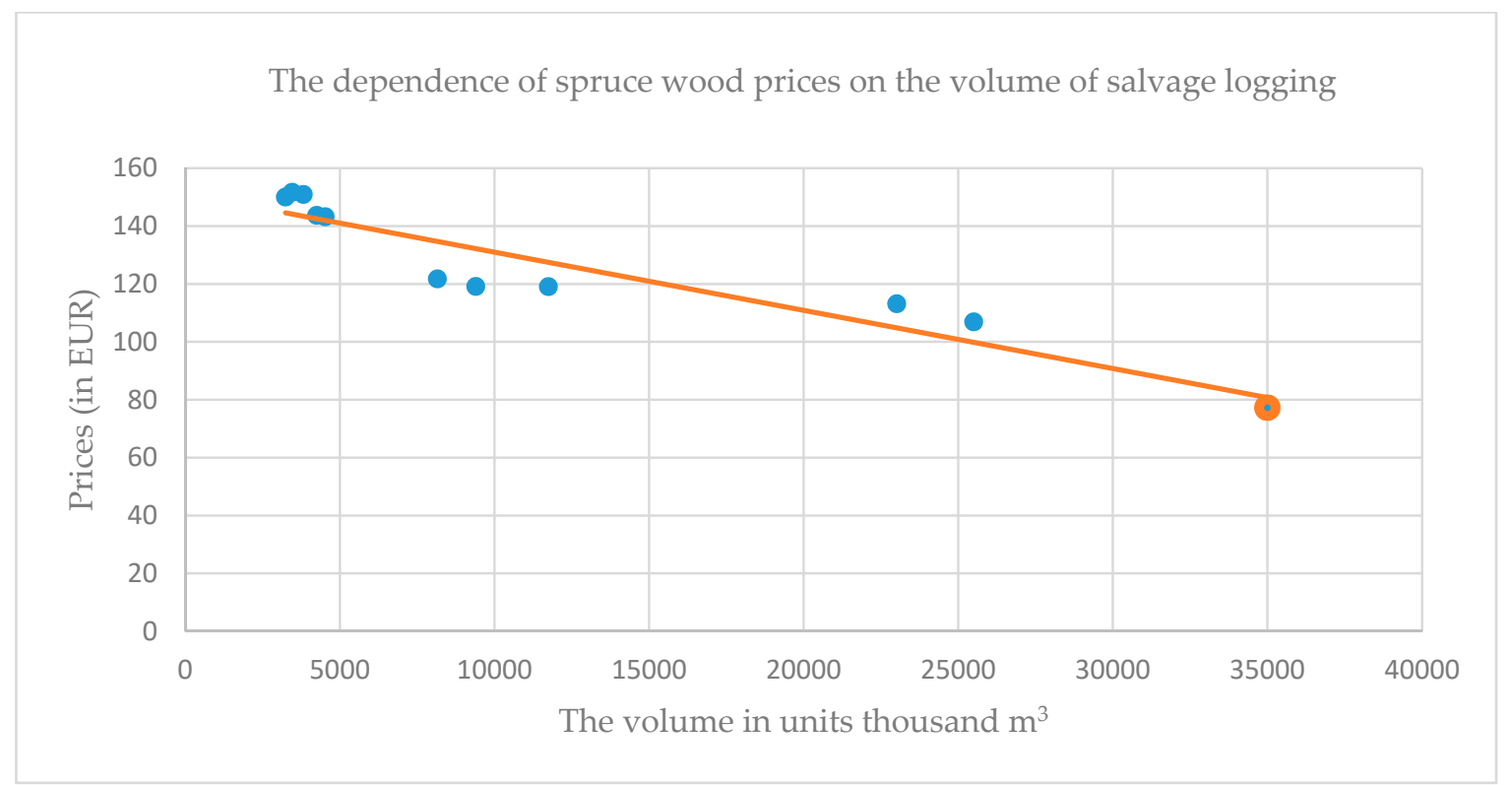

Figure 5. The estimation of the price of spruce wood depending on the volume of incidental logging; Source: Own calculations; Result of regression model: $y=-0.002 x+151.09 ; R^{2}=0.875$.

In our case, the regression coefficient is -0.05349 , which makes it possible to formulate an expected value. The regression equation further allows us to predict the value of the dependent variable from the values of the independent variable. With every million cubic meters of spruce wood harvested, the loss in the foresty sector increases by more than EUR 4.2 million. The result of this calculation aligns with economic theory, which posits that as the volume of production of a good increases, its price decreases. We were interested in the extent to which this theory corresponds to our results, as well as how much the prices are reduced when the production of the good increases.

\section{Discussion}

The results show that the volume of unplanned logging in the Czech Republic is very strongly reflected in the decline of raw timber prices. This conclusion is consistent with the economic theory and experience of other countries [7]. Most of the decline in revenue concerns state-owned enterprises [3]. However, the fall in wood prices has most affected forestry workers [8]. Employees receive the lowest average nominal wages of all industries in the Czech Republic. In 2019, employees in forestry received less than EUR 990 in comparison to the average gross nominal wage in the Czech Republic of EUR 1.35 thousand (in the third quarter of 2019) [9]. Other negative impacts of excessive logging in the Czech Republic are reduced carbon binding $\left(\mathrm{CO}_{2}\right)$ [10] and reduced water retention in soil [11].

The prediction of timber harvesting volume is important [12], as is the prediction of the impact of unplanned logging on the price of raw spruce [9]. The problem affects not only most European countries, but also the United States [9] and Canada, both major wood-producing countries. The bark beetle calamity, caused mainly by the spruce bark beetle, must therefore be understood as a global problem [13] caused to a certain extent by climate change, global warming, and the slow or erroneous action of forest management [9]. Although some authors argue that global climate change may result in increased bio-mass growth and wood growth [14], global changes in the Czech Republic, Germany, and Austria have resulted in rather negative effects on forest growth: drought, the increasing fragility of trees due to atmospheric flow, [15] and the increased activity of biotic factors. Thus, yields from wood production have also decreased dramatically. In forestry and economic literature, however, the prevailing view is that the greatest losses are not associated with excessive unplanned logging but rather with forest regeneration. The fall in the price of wood does not create additional financial resources for future forest regeneration, thus potentially endangering the entire forestry sector in the 
Czech Republic. Financial resources for forest restoration is the responsibility of national environmental policy agencies in the global fight against climate change, but is not a goal of forest owners and timber producers [16]. An equally important tool for the effective restoration of a species-rich and suistanable forest [17] will be the implementation of new forestry technologies and practices [18] which should accelerate and improve forest planting and regeneration in the Czech Republic. The application of new technologies and environmental innovations should serve [16] both to protect natural resources and effectively combat climate change [19], while also improving the socio-economic conditions of the forestry sector. The introduction of new technologies should allow for the rapid recovery of a forest [20] that can bind carbon from the atmosphere [19,20], produce wood that can serve as a biofuel [21], and retain more water in the landscape, thereby cooling the atmosphere. The secondary impact of rapid forest recovery is the long-term stabilization of annual logging [22-24] and hence also the stabilization of wood prices [25-28], including the sustainability of the whole foresty sector [29-34].

The decline in the price of spruce that is damaged by bark beetle corresponds to the rate of decline in prices in other European spruce-producing countries, mainly Austria, Germany, and Slovakia. These countries are the main producers of raw timber, as well as large importers of harvested timber from the Czech Republic. The price of spruce wood thus depends not only on the volume of mining, but also on the technological capacities of the processing countries [35-37]. The technological capacities of Austria and Germany are close to $100 \%$; therefore, further development depends on the ability and willingness of these countries to harvest raw timber in the Czech Republic.

\section{Conclusions}

Financial losses in the forestry sector due to the volume of unplanned logging amounted to more than EUR 1.12 million in the year 2019 in the Czech Republic alone. On a European scale, the bark beetle calamity can evoke the loss of hundreds of millions of EUR, respectively tens of billions of EUR, as the bark beetle calamity also affects other European countries, including Germany, Austria, and Slovakia. Most of these losses affect spruce producers and timber traders. These losses can be mitigated by the diversification of the international timber trade and the increasing trend of timber exports to China.

However, the long-term development of the price of spruce will depend on factors other than the volume of harvesting. A very important aspect is the development of a domestic demand for wood and wood products. Wood products are increasingly attractive materials for construction and household equipment; consumers prefer natural materials and wood for its physical and aesthetic qualities. Therefore, domestic demand may stabilize wood prices in the future. Another aspect will be a future decline in planned logging. Timber harvested in this time due to biotic factors will not be harvested to the same extent in the next five to six years. It can be assumed that the planned logging will be around one to two million $\mathrm{m}^{3}$ of wood per year. Reduced logging and timber production will create a gradual increase in the prices of raw timber and wood products.

The Ministry of Agriculture of the Czech Republic compensates forest owners for the short-term reduction in losses from the sale of surplus wood. The Ministry of Agriculture will compensate for the difference between the timber price received and the long-term average. Other tools are not yet available. In some states of the European Union, in order to promote trade and price formation in timber, the state began to deal with such a problem by buying wood for energy use or for state reserves (Austria and Germany). In the Czech Republic, this is not yet legally or practically possible. The purchase of timber by the state does not have sufficient legal support in the Czech Republic since there are no logistical prerequisites. The Ministry of Agriculture of the Czech Republic approaches the situation differently. On 29 November 2019, the Ministry of Agriculture began a program to provide additional financial support to non-state forest owners. The idea is to bring prices of coniferous timber to the level necessary to provide resources for forest regeneration and care. The expected budgetary impact, approved by the government, is EUR 100 million for 2019 and another EUR 80 million for 2020. However, the Ministry of the Environment of the Czech Republic should also include systematic support for forestry in its State Environmental Policy in 2020 to 2030. The sustainability of forestry is 
in the public interest. A healthy forest is able to maintain water in the landscape, improve air quality, bind $\mathrm{CO}_{2}$, protect the soil from harmful agents and erosion, improve landscaping and recreational functions, and significantly improve the quality of life. Forest management and forest regeneration is an important prerequisite for sustainability in the process of combating climate change. Those factors significantly influence timber prices of all sortiments of wood.

Author Contributions: Conceptualization, D.T. and M.M.; methodology, D.T.; software, K.M.; validation, V.J., D.T. and K.M.; formal analysis, V.J.; investigation, V.J.; resources, K.M.; data curation, D.T.; writing-original draft preparation, D.T.; writing—review and editing, D.T.; visualization, D.T.; supervision, M.M.; project administration, M.M.; funding acquisition, M.M. All authors have read and agreed to the published version of the manuscript.

Funding: This research received no external funding.

Acknowledgments: This paper was supported by the internal grant agency (IGA) of the Faculty of Economics and Management, Czech University of Life Sciences Prague, grant no. 2019B0011 "Economic analysis of water balance of the current agricultural commodities production mix in the Czech Republic" (Ekonomická analýza vodní bilance stávajícího produkčního mixu zemědělských komodit v ČR).

Conflicts of Interest: The authors declare no conflict of interest.

\section{References}

1. Kadavý, J.; Adamec, Z.; Uherková, B.; Kneifl, M.; Knott, R.; Kučera, A.; Friedl, M.; Dařenová, E.; Skládanka, J.; Drápela, K. Growth Response of Sessile Oak and European Hornbeam to Traditional Coppice-with-Standards Management. Forests 2019, 10, 515. [CrossRef]

2. Rehschuh, S.; Fuchs, M.; Tejedor, J.; Schäfler-Schmid, A.; Magh, R.-K.; Burzlaff, T.; Rennenberg, H.; Dannenmann, M. Admixing Fir to European Beech Forests Improves the Soil Greenhouse Gas Balance. Forests 2019, 10, 213. [CrossRef]

3. Cao, X.; Yang, S.; Huang, X.; Tong, J. Dynamic Decomposition of Factors Influencing the Export Growth of China's Wood Forest Products. Sustainability 2018, 10, 2780. [CrossRef]

4. Yang, H.; Harrison, R.; Yi, Z.-F.; Goodale, E.; Zhao, M.-X.; Xu, J.-C. Changing Perceptions of Forest Value and Attitudes toward Management of a Recently Established Nature Reserve: A Case Study in Southwest China. Forests 2015, 6, 3136-3164. [CrossRef]

5. Shrestha, P.; Stainback, G.A.; Dwivedi, P. Economic Impact of Net Carbon Payments and Bioenergy Production in Fertilized and Non-Fertilized Loblolly Pine Plantations. Forests 2015, 6, 3045-3059. [CrossRef]

6. Chudý, M.; Reschenhofer, E. Macroeconomic Forecasting with Factor-Augmented Adjusted Band Regression. Econometrics 2019, 7, 46. [CrossRef]

7. Granger, C.W.J.; Newbold, P. Spurious regressions in econometrics. J. Econom. 1974, 2, 111-120. [CrossRef]

8. Yang, H.; Yuan, T.; Zhang, X.; Li, S. A Decade Trend of Total Factor Productivity of Key State-Owned Forestry Enterprises in China. Forests 2016, 7, 97. [CrossRef]

9. Toth, D.; Maitah, M.; Maitah, K. Development and Forecast of Employment in Forestry in the Czech Republic. Sustainability 2019, 11, 6901. [CrossRef]

10. ČSÚ. Lesnictví. (Online). 2019. Available online: https://www.czso.cz/csu/czso/indexy-cen-v-lesnictvisurove-drivi-3-ctvrtleti-2019 (accessed on 1 January 2020).

11. Liu, J.; Wu, F. Forest Carbon Sequestration Subsidy and Carbon Tax as Part of China's Forestry Policies. Forests 2017, 8, 58. [CrossRef]

12. Shrestha, S.; Dwivedi, P.; McKay, S.K.; Radcliffe, D. Assessing the Potential Impact of Rising Production of Industrial Wood Pellets on Streamflow in the Presence of Projected Changes in Land Use and Climate: A Case Study from the Oconee River Basin in Georgia, United States. Water 2019, 11, 142. [CrossRef]

13. Štícha, V.; Sharma, R.; Vacek, Z.; Vacek, S.; Nuhlíček, O. Timber and Branch Volume Prediction: Effects of Stand and Site Characteristics on Dendromass and Timber-To-Branch Volume Ratio of Norway Spruce in Managed Forests. Forests 2019, 10, 144. [CrossRef]

14. She, J.; Chung, W.; Han, H. Economic and Environmental Optimization of the Forest Supply Chain for Timber and Bioenergy Production from Beetle-Killed Forests in Northern Colorado. Forests 2019, 10, 689. [CrossRef]

15. Holmes, T.; Koch, F. Bark Beetle Epidemics, Life Satisfaction, and Economic Well-Being. Forests 2019, 10, 696. [CrossRef] 
16. Susaeta, A.; Lal, P. Impacts of Climate Change and Bioenergy Markets on the Profitability of Slash Pine Pulpwood Production in the Southeastern United States. Forests 2018, 9, 656. [CrossRef]

17. Oldfield, C.; Peterson, C. Woody Species Composition, Diversity, and Recovery Six Years after Wind Disturbance and Salvage Logging of a Southern Appalachian Forest. Forests 2019, 10, 129. [CrossRef]

18. Dvouletý, O.; Blažková, I. The Impact of Public Grants on Firm-Level Productivity: Findings from the Czech Food Industry. Sustainability 2019, 11, 552. [CrossRef]

19. Lu, H.; Mohren, G.M.J.; Del Río, M.; Schelhaas, M.-J.; Bouwman, M.; Sterck, F.J. Species Mixing Effects on Forest Productivity: A Case Study at Stand-, Species- and Tree-Level in the Netherlands. Forests 2018, 9, 713. [CrossRef]

20. Kapilakanchana, M.; McCarl, B.A. The Effect of Technological Progress, Demand, and Energy Policy on Agricultural and Bioenergy Markets. Atmosphere 2020, 11, 31. [CrossRef]

21. Amaral, M.; Lima, A.; Higuchi, F.; dos Santos, J.; Higuchi, N. Dynamics of Tropical Forest Twenty-Five Years after Experimental Logging in Central Amazon Mature Forest. Forests 2019, 10, 89. [CrossRef]

22. da Rocha Júnior, R.L.; dos Santos Silva, F.D.; Lisboa Costa, R.; Barros Gomes, H.; Herdies, D.L.; Rodrigues da Silva, V.P.; Candido Xavier, A. Analysis of the Space-Temporal Trends of Wet Conditions in the Different Rainy Seasons of Brazilian Northeast by Quantile Regression and Bootstrap Test. Geosciences 2019, 9, 457. [CrossRef]

23. Russo, D.; Marziliano, P.A.; Macrì, G.; Zimbalatti, G.; Tognetti, R.; Lombardi, F. Tree Growth and Wood Quality in Pure Vs. Mixed-Species Stands of European Beech and Calabrian Pine in Mediterranean Mountain Forests. Forests 2020, 11, 6. [CrossRef]

24. Pirker, J.; Mosnier, A.; Nana, T.; Dees, M.; Momo, A.; Muys, B.; Kraxner, F.; Siwe, R. Determining a Carbon Reference Level for a High-Forest-Low-Deforestation Country. Forests 2019, 10, 1095. [CrossRef]

25. Pukkala, T. Carbon forestry is surprising. For. Ecosyst. 2018, 5, 11. [CrossRef]

26. Hönig, V.; Prochazka, P.; Obergruber, M.; Smutka, L.; Kučerová, V. Economic and Technological Analysis of Commercial LNG Production in the EU. Energies 2019, 12, 1565. [CrossRef]

27. Kilham, P.; Hartebrodt, C.; Kändler, G. Generating Tree-Level Harvest Predictions from Forest Inventories with Random Forests. Forests 2019, 10, 20. [CrossRef]

28. Ning, Y.; Liu, Z.; Ning, Z.; Zhang, H. Measuring Eco-Efficiency of State-Owned Forestry Enterprises in Northeast China. Forests 2018, 9, 455. [CrossRef]

29. Ochuodho, T.; Alavalapati, J.; Lal, P.; Agyeman, D.; Wolde, B.; Burli, P. Potential Economic Impacts of Allocating More Land for Bioenergy Biomass Production in Virginia. Forests 2019, 10, 159. [CrossRef]

30. Choi, W.; Park, Y. Monitoring, Assessment and Management of Forest Insect Pests and Diseases. Forests 2019, 10, 865. [CrossRef]

31. Callaghan, D.W.; Khanal, P.N.; Straka, T.J.; Hagan, D.L. Influence of Forestry Practices Cost on Financial Performance of Forestry Investments. Resources 2019, 8, 28. [CrossRef]

32. Lundholm, A.; Corrigan, E.; Nieuwenhuis, M. Implementing Climate Change and Associated Future Timber Price Trends in a Decision Support System Designed for Irish Forest Management and Applied to Ireland's Western Peatland Forests. Forests 2019, 10, 270. [CrossRef]

33. Zhuang, Q.; Wu, S.; Yan, Y.; Niu, Y.; Yang, F.; Xie, C. Monitoring land surface thermal environments under the background of landscape patterns in arid regions: A case study in Aksu river basin. Sci. Total Environ. 2020, 710, 136336. [CrossRef] [PubMed]

34. Banaś, J.; Kożuch, A. The Application of Time Series Decomposition for the Identification and Analysis of Fluctuations in Timber Supply and Price: A Case Study from Poland. Forests 2019, 10, 990. [CrossRef]

35. Mozgeris, G.; Brukas, V.; Pivoriūnas, N.; Činga, G.; Makrickienė, E.; Byčenkienè, S.; Marozas, V.; Mikalajūnas, M.; Dudoitis, V.; Ulevičius, V.; et al. Spatial Pattern of Climate Change Effects on Lithuanian Forestry. Forests 2019, 10, 809. [CrossRef]

36. Maitah, M.; Procházka, P.; Smutka, L.; Maitah, K.; Honig, V. Analysis of the Impact of Ethanol Production on Agricultural Product Prices in Brazil. Sugar Tech. 2019, 21, 773-779. [CrossRef]

37. Gebeltová, Z.; Malec, K.; Maitah, M.; Smutka, L.; Appiah-Kubi, S.N.K.; Maitah, K.; Sahatqija, J.; Sirohi, J. The Impact of Crop Mix on Decreasing Soil Price and Soil Degradation: A Case Study of Selected Regions in Czechia (2002-2019). Sustainability 2020, 12, 444. [CrossRef]

(C) 2020 by the authors. Licensee MDPI, Basel, Switzerland. This article is an open access article distributed under the terms and conditions of the Creative Commons Attribution (CC BY) license (http://creativecommons.org/licenses/by/4.0/). 